\title{
Monastic Control over Agriculture and Farming
}

\author{
New Evidence from the Egyptian Monastery of Apa Apollo at Bawit \\ Concerning the Payment of APARCHE
}

\author{
Gesa Schenke
}

Looking at the publications by Sarah J. Clackson ${ }^{1}$ and Alain Delattre ${ }^{2}$ of the rich documentary evidence from the monastery of Apa Apollo at Bawit in Middle Egypt, we encounter a largely self-sufficient monastic entity. Everything needed for a bearable life on earth could be supplied from within the monastery. Food and wine from land owned by the monastery and farmed or managed by members of the monastic community filled the tables and was apparently in such abundance that it could be used as payments in kind to people within and outside the community. ${ }^{3}$ Presumably, community members were also educated within the monastery in crafts and skills, such as farming, building, carpentry, weaving, accounting, and writing, as well as nursing the sick in the monastery's own infirmary. 4

* This contribution has benefitted from the lively and enjoyable round table discussion held in Leiden, whose participants are hereby warmly thanked. Research for this article was undertaken as part of the ERC project The Formation of Islam. The View From Below (Leiden University 2009-2014). In the meantime, new texts concerning the monastery of Apa Apollo at Bawit and the collection of aparche have been published in Gesa Schenke, Kölner ägyptische Papyri (P.Köln ägypt.), vol. 2, Koptische Urkunden der früharabischen Zeit, Abhandlungen der Nordrhein-Westfälischen Akademie der Wissenschaften und der Künste, Papyrologica Coloniensia 9, no. 2 (Paderborn: Schöningh, 2016), 1-10o (the monastery of Apa Apollo at Bawit), esp. 47-66 (new texts concerning the aparche). Much of the German discussion there is based on this contribution.

1 Sarah J. Clackson, Coptic and Greek Texts Relating to the Hermopolite Monastery of Apa Apollo (Oxford: Alden Press, 200o) and Sarah J. Clackson, It Is Our Father Who Writes: Orders from the Monastery of Apollo at Bawit (Cincinnati: American Society of Papyrologists, 2008) [= P.Mon.Apollo and P.Bawit Clackson].

2 Alain Delattre, Papyrus coptes et grecs du monastère d'apa Apollô de Baouît conservés aux Musées royaux d'Art et d'Histoire de Bruxelles (Bruxelles: Académie Royale de Belgique, 2007) $[=$ P.Brux.Bawit $]$.

3 Wine, e.g. P.Brux.Bawit 4-10 and 22; oil, P.Brux.Bawit 11-12; bread, P.Brux.Bawit 14-16; dried meat, P.Brux.Bawit 13, 24, and 26; vegetables, P.Brux.Bawit 12.

4 пма мNєто)ळne ("the place for the sick") cf. P.Brux.Bawit 1,2 and possibly 2,2.

(C) THE AUTHOR, 2019 | DOI:10.1163/9789004386549_014

This is an open access chapter distributed under the terms of the CC-BY-NC 4.o license 
Whether the monastery of Apa Apollo was organized in the form of a coenobium based on the Pachomian model or in a more loose arrangement is a question of much debate. ${ }^{5}$ The archaeological remains show a village-like arrangement with a number of churches, kitchens, ovens, dining halls, storage facilities, a bath, possibly a school, a library, an infirmary, private living quarters, gardens, and fields, ${ }^{6}$ all of which are reflected in the documentary sources. The frequent interactions between members of the monastery and laypeople in legal and financial matters ${ }^{7}$ seem to speak for a more loosely knit type of monastic community. Monks and laypeople could function as witnesses for each other, make or receive payments in money or kind, lend or borrow money, and be employed for particular jobs, such as building or field work and land management.

The land owned by the monastery seems to have been very extensive so that it would have needed many monks to work it. From the evidence available, however, it appears that monks did not only personally cultivate monastic land in the Hermopolite nome, ${ }^{8}$ but also managed its farming through leasing the land and employing local workers, much in the way of (great) landowners. ${ }^{9}$

\section{Documenting the Payment of Aparche}

In the first published collection of Coptic and Greek texts relating to the monastery of Apa Apollo at Bawit (P.Mon.Apollo), about a third of the texts therein, that is, more than 20 documents, are concerned with the payment of what is called the aparche, a Greek term that denotes the "first fruits" of the land's yearly produce presented to an ecclesiastical or monastic institution. ${ }^{10}$

Cf. Clackson, Coptic and Greek Texts, 8, as well as the summary of opinions in Delattre, Papyrus coptes et grecs, $5^{8-74}$.

6 For this, see most recently Delattre, Papyrus coptes et grecs, 45 (with note 87), 47-54 and 85 , on ovens in Bawit.

7 Cf. the short summary in Clackson, Coptic and Greek Texts, $31 \mathrm{f}$.

8 The suggestion that the monastery owned land in the Fayyum (Clackson, Coptic and Greek Texts, 21f.) has been refuted by Delattre, Papyrus coptes et grecs, 86 .

9 The management of monastic land cultivation has been discussed by Ewa Wipszycka, "Resources and Economic Activities of the Egyptian Monastic Communities (fourtheighth Century)," The Journal of Juristic Papyrology 41 (2011): 199-207. Landed property of the monastery of Apa Apollo at Bawit is discussed in Ewa Wipszycka, Moines et communautés monastiques en Égypte (IVe-VIIIe siècles), JJP Supplement XI (Warsaw: Journal of Juristic Papyrology, 2009), 545-565. See also Alain Delattre, "Une liste de propriétés foncières du monastère d' Apa Apollô de Baouît," Zeitschrift für Papyrologie und Epigraphik 151 (2005): 163-165.

For a discussion of the term $\dot{\alpha} \pi \alpha p \chi \eta \dot{~(" p r i m a l ~ o f f e r i n g " ~ o r ~ " f i r s t ~ f r u i t s ") ~ i n ~ t h e ~ c o n t e x t ~ o f ~}$ 
In the documents from Bawit, all assigned to the seventh and eighth centuries on the basis of the script, the aparche is due at the time of the harvest of a particular indiction year. In these texts, addressed to monastic representatives, monks accept the responsibility for specific fields for which they guarantee to obtain the payment of aparche as well as to "be responsible for" the amount of pactum ("rent") or demosion ("land-tax") due for this very plot of land. This procedure was organized by way of guarantees and contracts or receipts.

These aparche documents, known so far only from the monastery of Apa Apollo at Bawit, offer a glimpse into the monastery's organization of farming and controlling the produce of their land. Moreover, a look into the microcosm of the Bawit monastery allows for an understanding of how the community's land-taxes were collected - here we have to bear in mind that these texts have been considered a major source of evidence on tax collection in early Islamic Egypt.

Sarah Clackson, the editor of P.Mon.Apollo, called these documents tithe collection guarantees (P.Mon.Apollo 1-7) and tithe collection contracts (P.Mon. Apollo 8-14), while others were referred to as 'other tithe and pactum collection texts' (P.Mon.Apollo 15-23). The first category of such texts shows a monk of the monastery of Apa Apollo acknowledging to one or more of his fellow monks that he has received from them (responsibility over) a particular place in the countryside, from which he guarantees to obtain payment. The second category attests the handing over of such a place to a monk for the same purpose. As both parties in these documents are monks of one and the same monastery, the need to record this procedure in writing illustrates its importance. These guarantees and contracts are given for one specific indiction only, and must have, therefore, become numerous over time.

The nature and precise purpose of these documents have been the subject of debate, especially since no document has been preserved in its entirety. ${ }^{11}$

monastic land cultivation see Wipszycka, "Resources and Economic Activities," 205-206; Wipszycka, Moines, 559-561; Ewa Wipszycka, Les resources et les activités économiques des églises en Égypte du iv ${ }^{e}$ au viiie siècle (Brussels: Fondation égyptologique Reine Elisabeth, 1972), 70-71.

11 See the remarks by Tonio Sebastian Richter, "The Cultivation of Monastic Estates in Late Antique and Early Islamic Egypt: Some Evidence from Coptic Land Leases and Related Documents," in Monastic Estates in Late Antique and Early Islamic Egypt (P.Clackson), eds. Anne Boud'hors, James Clackson, Catherine Louis and Petra Sijpesteijn (Cincinnati: American Society of Papyrologists, 2009), 210-212, as well as Richter's review of Clackson, Coptic and Greek Texts: Tonio Sebastian Richter, "Ein neues Dossier zur KlosterPapyrologie," Orientalistische Literaturzeitung 99 (2004):172-176. See also the summary in Delattre, Papyrus coptes et grecs, $96 \mathrm{f}$. 
Additionally, a number of problematic assumptions have caused confusion. A model text for a "tithe collection guarantee", piecing together the various preserved parts, has been suggested to run on the following lines:

I, brother NN, monk of the topos of the holy Apa Apollo of the mount of Titkooh in the district of Hermopolis, am writing to my brother NN and brother NN, monks of the same topos of the holy Apa Apollo. After we have agreed with one another, you have given me the place $\mathrm{X}$, so that I collect its aparche for (the monastery of) Apa Apollo in the harvest of this year, the indiction year $\mathrm{Y},-$ for its demosion/pactum which makes [number] solidi. Now then, by the will of God, I shall give it to you without judgement, without law, and without any objection. After that the statements of witnesses follow.

A "tithe collection contract" in turn would be phrased the other way around:

I, brother NN, monk of the topos of the holy Apa Apollo, am writing to my brother NN, monk of the same topos of the holy Apa Apollo. After we have agreed with one another, I have given you the place $\mathrm{X}$, so that you collect its aparche for (the monastery of) Apa Apollo in the harvest of this year, the indiction year Y, - for its demosion/pactum which makes [number] solidi, and so on.

These two document types seem to be variations of each other rather than counterparts handed to each party, or the second type functioning as a receipt of the payment, i.e., the fulfilment of the guarantee given, as has been suggested. ${ }^{12}$ They differ in one aspect only, that is, in their being phrased in opposite ways, the first from the perspective of the recipient of the responsibility for a place from which he is to collect the aparche, the other from that of the person who assigns this responsibility. This phenomenon reminds one of the phrasing of leases employing either the misthosis or antimisthosis formula, formulated either from the perspective of the lessee (misthosis) or that of the lessor (antimisthosis). ${ }^{13}$

12 Cf. Richter, "Ein neues Dossier," 173.

13 For the latest discussion of misthosis and antimisthosis documents, see Florence Lemaire, "Antimisthosis in the Dioscorus Archive," in Proceedings of the Twenty-Fifth International Congress of Papyrology, Ann Arbor 2007, ed. Traianos Gagos, American Studies in Papyrology (Ann Arbor: University of Michigan Press, 2010), 399-40o, with notes 11 and 18. 
The editor's decision to translate the Greek term aparche (meaning "first fruits") as "tithe" and to refer to the documents as "tithe collection guarantees" and "tithe collection contracts", gives the impression that the monks were giving a guarantee to collect a mandatory payment of $10 \%$ of the year's harvest from the tenants of certain plots. The editor then goes on to assume that the precise equivalent of this $10 \%$ was stated at the end of the document in solidi and was described as pactum ("rent") in some documents and as demosion ("land-tax") in others. Therefore, the term aparche has been identified with the term demosion or pactum, and aparche has been thought to be the rent due for Bawit land leases. ${ }^{14}$

To be sure, the documents never speak of any specific amount when they mention aparche, and we cannot assume that aparche was a precisely calculated percentage of whatever produce the land provided at the harvest of a given year. This would have been subject to a lease contract drawn up much earlier between the tenants of the land and the monastery as its lessor, specifying the type and amount of produce to be offered to the monks during the harvest.

What seems to have further hampered the understanding of the nature of these documents is the assertion that the monastery would not have asked their tenants for the payment of two different things, i.e., a fraction of the harvest as well as payment for rent (pactum) or land-tax (demosion). Therefore, the terms aparche and pactum (or aparche and demosion) were thought to refer to one and the same payment, for which a certain amount is always given in solidi. ${ }^{15}$

Such a hypothesis does not engage with the grammatical constructions employed in these formulas, nor does it take account of the realities on the ground. ${ }^{16}$ The monastery as a whole was required to pay taxes on its land, i.e.,

14 Contested by Wipszycka on the grounds that the term aparche otherwise never occurs in land leases; see Ewa Wipszycka, "Le fonctionnement interne des monastères et des laures en Égypte du point de vue économique: à propos d'une publication récente de textes coptes de Bawit," The Journal of Juristic Papyrology 31 (2001): 185.

15 Clackson, Coptic and Greek Texts, 18b: "The taxes gathered by a monastery from its landtenants can include aparchê, translated as 'tithe' (...). This interpretation is the most appropriate for the texts in this edition because they specify that the tithe is then paid out as a tax-rent designated pactum or dêmosion (...). It is unlikely that a monastery would have demanded a tithe from its land tenants in addition to a tax-rent payment." See also Sarah J. Clackson, "Archimandrites and Andrismos: A Preliminary Survey of Taxation at Bawit," in Akten des 23. Internationalen Papyrologenkongresses, Wien, 22.-28. Juli 2001, ed. Bernhard Palme (Wien:Verlag der Österreichischen Akademie der Wissenschaften, 2007), 106: "The monks undertook to use whatever aparchê they collected, in the form of goods or money, to pay the dêmosion and pactum due from specific places assigned to them".

16 For this, cf. the note of Tonio Sebastian Richter in his review on Clackson, Coptic and 
demosion. This term seems to be used interchangeably with the term pactum in these documents. Why the monastery should have paid the full amount of land-taxes without receiving at least a fraction of the produce has remained unexplained. It would seem only sensible for the monastery to demand from their tenants the amount in rent (pactum) that it owed to the state as land-tax $(\text { demosion })^{17}$ in addition to a part of the harvest; otherwise there would be no gain for the monastery from the leasing of its property.

The monk who assumes responsibility for an allocated field's rent or land-tax payment seems to function much in the way of a tax collector. He undertakes to obtain the payments from tenants who farm monastic property, but if the tenants were unable to pay, he would be held financially liable for the missing amount. It is thus not the monastery as a whole, but individual members of the community who act as guarantors of the monastery's land-tax payment, ready to cover a lack of funds.

In addition to that financial guarantee, monks committed themselves to obtaining the first fruits from the leased land for the benefit of the monastery as a whole and as the legal owner of that land..$^{18}$

The double occurrence of the Coptic preposition 2d-in connection with the verb coK in these documents suggests that the two different terms (aparche and pactum/demosion) occurring in these documents refer to two different kinds of payment. In the first instance the verb cok is used with aparche as the direct object followed by the preposition 2a- to designate the beneficiary (P.Mon.Apollo 1,10-11; 2,8; 3,5-6; 4,5; 5,x+10; 6,x+2; 9,6; 10,8-10; 11,4-8; $12,3 ; 14,4-5 ; 15,3-4)$. The verb coK possesses a large range of meanings, but none of them include "to collect (from other people)". A more literal mean-

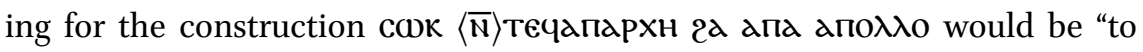

Greek Texts, that e.g. in Talmud law a religious form of tithe payment in addition to farm rent is well known (Richter, "Ein neues Dossier," 174). See also the remark by Wipszycka, "Resources and Economic Activities," 206: "I would rather assume that the monastery tried to force the peasants who tilled monastic land to pay a tithe besides the rent."

17 See already Clackson, Coptic and Greek Texts, 19b: "Both pactum and dêmosion are left untranslated, as they can mean 'rent' or 'tax' in this situation: the term tax-rent is appropriate because the tenants' rent would pay the land taxes owed to the state." with reference to Jean Gascou, "Les grands domaines, la cité et l' état en Égypte byzantine (recherches d'histoire agraire, fiscale et administrative)," Travaux et Mémoires: Centre de Recherches d'histoire et de civilisation byzantines 9 (1985): 15 .

18 The summary given by Wipszycka, "Resources and Economic Activities," 206, on the collection procedure documented in these aparche texts, suggesting that the individual monk would keep parts of the collected payment for himself, seems to be the direct opposite. Instead he is providing a service to his monastic community by supporting it financially, if need be. 
obtain its aparche on behalf (of the monastery) of Apa Apollo". Following the reference to the indiction, in a number of documents the preposition $2 \mathrm{~d}-$ occurs again, this time in connection with the term for the rent or land-tax payment and apparently grammatically unconnected with the former sentence (P.Mon.Apollo 1,12; 2,10; 3,7). Some of the aparche contracts make it clear that this is a second duty expected of the monk to perform, by employing the verb †-/Tı-, "to pay" (P.Mon.Apollo 6,x+3: Tı пеүпакте; P.Mon.Apollo 9,7: † печпактоn; P.Mon.Apollo 11,9-10: тї пеүпактоN, and P.Mon.Apollo 13,3: тІ пєвпактОN) in the form of the conjunctive following the causative infinitive of the verb cळк: "in order for me/you to obtain its aparche on behalf (of the monastery) of Apa Apollo and to pay its rent."

In the documents lacking a second verb ( $\left.\boldsymbol{t}^{-} / \mathrm{Tl}^{-}\right)$but adding the preposition 2d-before the rent payment, one could consider that the construction 2a neqпактоN was governed by the causative infinitive of the verb coк mentioned earlier in the text, but with a change in the meaning indicated by that preposition. A particular use for coK 2d- is "to be responsible for" or "to pay for", 19 so that the alternative phrasing in these documents would be: “... in order for me/you to obtain its aparche on behalf (of the monastery) of Apa Apollo and in order for me/you to be responsible for/to pay for its rent." ${ }^{20}$

The first fruit payment (aparche), made in kind, would be directly for the benefit of the monastery as the owner of the land, while the money payment for pactum or demosion would cover the cost for the land-tax (demosion), which the monastery had to pay to the state.

Since these aparche documents are concerned with obtaining the produce of land cultivated by tenants of the monastery and with securing through the tenants' rent (pactum) the amount of land-tax the monastery had to pay yearly for its properties, there must have been land leases contracted prior to this proce-

19 Walter C. Till, "Beiträge zu W.E. Crums Coptic Dictionary," Bulletin de la Société d'Archéologie copte 17 (1963-1964): 202: CWK 2d- "für etwas aufkommen," with reference to CPR IV 111, 5. For a collection of the available evidence, see now Tonio Sebastian Richter, Rechtssemantik und forensische Rhetorik: Untersuchungen zu Wortschatz, Stil und Grammatik der Sprache koptischer Rechtsurkunden (Leipzig: Verlag Helmar Wodtke und Katharina Stegbauer GbR, 2002), revised edition (Wiesbaden: Harrassowitz, 2008), 258-259.

20 Just as in P.Mon.Apollo 25, where a monk has been successful in having the monastery redistribute one of two places he had under his care to another monk, "so that he (i.e. the other monk) is responsible for/pays for its demosia" (line 6: етревсок 2а мес $\triangle$ нмосіом). 
dure. The term pactum suggests that the lease ran for one year only, as seems to have been common practice. ${ }^{21}$ Leases must have specified the amount of rent tenants had to pay, and perhaps hinted to an agreement over the amount and type of first fruit payments expected by the lessor, even if such an agreement was not part of the written lease.

Coptic land leases such as $C P R$ IV 126 and 127 explicitly state that nothing apart from the agreed amount for pactum will be asked of the lessee, i.e., no hidden costs in the form of payment to any official body. That, however, seems to suggest, that such additional payments were quite common, perhaps even in the form of first fruits. Greek land leases of the Byzantine period not infrequently include a promise to perform some extra service in addition to the expected rent payment, which in most cases concerns a delivery of agricultural commodities. ${ }^{22}$

So far the only clear misthosis document from the Bawit monastery, P.Mon. Apollo 26, is one in which two of its own monks are the lessees of a plot of monastic land. This text differs from other known Coptic land-leases, ${ }^{23}$ so much so that perhaps we have to posit that scribes of the Bawit monastery used formulas not common elsewhere. Next to the peculiar peneiot petshai and the anokpason formulae, we might be dealing with an unusual misthosis document and several idiosyncratic aparche documents requiring an additional payment of aparche besides the rent/tax paid for the lease. This is not in line with known formulas of Coptic land-leasing documents, ${ }^{24}$ where presumably the amount paid for rent includes a margin of profit, so that no other charges are claimed. But if the rent paid to the monastery only included the amount required from the monastery as land tax, then the profit for the monastery as a landlord had to come through a different type of "gift" or payment most likely to be made in kind.

21 Cf. Richter, "Cultivation of Monastic Estates," 211, where he states that "pakton generally means the rent to be paid for one-year leases." For terms other than pactum in leases, cf. also Tonio Sebastian Richter, "Koptische Mietverträge über Gebäude und Teile von Gebäuden," The Journal of Juristic Papyrology 32 (2002):116-119, as well as Tonio Sebastian Richter, "Alte Isoglossen im Rechtswortschatz koptischer Urkunden," Lingua Aegyptia 10 (2002): 389-399.

22 For a discussion of these texts, see Klaas A. Worp, "Deliveries for CYNH@EIA in Byzantine Papyri," in Essays and Texts in Honor of J. David Thomas, eds. Traianos Gagos and Roger S. Bagnall (Cincinnati, Ohio: American Society of Papyrologists, 20o1), 51-68.

23 Cf. Richter, "Cultivation of Monastic Estates," 209.

24 For a quick overview on Coptic land leases from the Fayyum, the Hermopolite nome, and the Theban area, their formulars and different terminology, see Richter, "Cultivation of Monastic Estates," 205-207. 
Amounts mentioned in solidi for the rent/land-tax payment in aparche documents vary greatly, presumably according to the type and size of land. Unfortunately they are rarely preserved, with only four documents retaining an amount: P.Mon.Apollo 3, nearly two solidi, P.Mon.Apollo 2, exactly 19 solidi, P.Mon.Apollo 10, nearly 18 solidi, and P.Mon.Apollo 11, nearly 16 solidi. ${ }^{25}$ From these amounts we may infer that the monastery had large parts of their property leased to non-monastic tenants. This must have provided employment for many people in neighbouring villages, who had the chance to make up for lack of private land by cultivating such property. In doing so they were working "holy land", helping to "feed the monks" through their labour, which could be seen as proper Christian behaviour.

A payment of aparche was not solely destined for the monastery of Apa Apollo. Other monasteries are mentioned as well, such as those of Apa Anoup and Apa Jeremias (P.Mon.Apollo 11), of Apa Makare (P.Mon.Apollo 3$),{ }^{26}$ and Apa Mena (P.Mon.Apollo 16). In a contract from Djeme concerning the cultivation of land the payment for the scribe of the document is mentioned to be a tenth of the aparche (O.Crum sT 38 ).

If we assume that there had been an agreement between tenants and the monastery over a payment of aparche, the question arises just how much of a year's harvest was defined as aparche. Was it a fraction of first fruits being handed over for the benefit of the monastic community, or perhaps even literally offered at the shrine of the monastery's founding father? Or was it a way of referring to the produce of monastic land? That is, did the lessees work the land mainly for the benefit of the monastery or for their own? If the latter, which would be reasonable, the year's harvest minus the aparche and rent payment would be for the benefit of the lessees only. But as the monastery's management would need to obtain a wide range of products, it may have arranged with the lessees in advance what was to be planted and harvested, even though this is not stated in the documents.

25 Cf. also Clackson, Coptic and Greek Texts, 21a. While P.Mon.Apollo 2 only preserves this large amount on the reverse of the document (for which no image is provided) it is not entirely clear whether it is indeed connected to the aparche text. P.Mon.Apollo 10 is badly damaged, but seems to refer to a number of places for which pactum is to be paid. Likewise, P.Mon.Apollo 11 refers not only to more than one place, but also to pactum payments for three different monasteries. Finally, in line $16 \mathrm{f}$. one finds the statement that "all the brothers shall pay it," which could well account for the high amount in solidi mentioned.

26 Cf. Clackson, Coptic and Greek Texts, 19 and 23, as well as Delattre, Papyrus coptes et grecs, 65 , note 188 . 
Tenants of land belonging to the monastery of Apa Apollo at Bawit seem to have paid a fraction of the year's harvest, referred to as aparche or first fruits, in addition to an amount of money for rent (or land-tax), referred to as pactum (or demosion). The properties mentioned in the Bawit documents are specific allocated places with one-year leases, in accordance with other Coptic leasing documents of the early Islamic period. Members of the monastic community who acknowledge that these two payments are due to the monastery seem to be members of the community in charge of obtaining produce and rent payments for the monastery, but ready to step in personally and to cover any financial loss on the part of their community. This seems to be the reason why the monastery's diakonia did not deal with tenants of monastic lands directly, but assigned the yearly responsibility to individual monks. ${ }^{27}$ In this way, the monastery as a whole did not have to shoulder the (full) fiscal responsibility for its landed property, but enjoyed the security provided by some of its members.

Monasteries such as that of Apa Apollo at Bawit seem to have retained total control over their land as well as over the choice of who was to work and manage it. They were also powerful enough to demand extra compensation for providing land and the opportunity for local tenants to make a living. In that respect the monastery at Bawit seems to have functioned as an economic unit, much in the way of other large estate holders.

The interchange of the two terms pactum and demosion, both referring in these documents to a rent payment, might be explained by the fact that the amount paid to the monastery in rent was in fact what the monastery paid as land-tax to the state. While the world of the Apa Apollo community seems byand-large free from any interference on the part of the new Muslim rulers, the frequent mention of tax-payments might, however, offer us a glimpse into the monastery's fiscal challenges under this new reign.

Apart from a few instances where people with Arab names occur in the Bawit documents as recipients of small commodities, such as wine (P.Mon.Apollo 45), boiled wine (P.Hermitage Copt. 16), or boiled wine and honey (P.Camb. UL inv. 1262, P.Brux. Bawit 27), ${ }^{28}$ the monastery of Apa Apollo at Bawit seems to have had little direct interaction with the new authorities. On the whole, the

27 A question raised by Wipszycka, "Resources and Economic Activities," 206.

28 See the recent overview of the published Bawit documents with summaries of their discussion and the latest 'Forschungsstand' given by Joanna Wegner, "The Bawit Monastery of Apa Apollo in the Hermopolite Nome and its Relations with the 'World Outside', The Journal of Juristic Papyrology 46 (2016): 147-274, especially 16o-162 and 191-197 for a sum- 
monastery seems to have stood firm as an independent and largely impenetrable unit opposing any outside authority and control for quite some time. As far as the current documentary evidence stands, it demonstrates the limits faced by the new administration in the seventh/eighth century to gain access to and control over such a close-knit and influential community. Disregarding the regular demands for taxes, authority in the Egyptian countryside seems to have remained largely in the hands of powerful local religious and economic institutions.

\section{Bibliography}

Clackson, Sarah J. Coptic and Greek Texts Relating to the Hermopolite Monastery of Apa Apollo. Oxford: Alden Press, 2000.

Clackson, Sarah J. "Archimandrites and Andrismos: A Preliminary Survey of Taxation at Bawit." In Akten des 23. Internationalen Papyrologenkongresses, Wien, 22.-28. Juli 2001, edited by Bernhard Palme, 103-107. Wien: Verlag der Österreichischen Akademie der Wissenschaften, 2007.

Clackson, Sarah J. It Is Our Father Who Writes: Orders from the Monastery of Apollo at Bawit. Cincinnati: American Society of Papyrologists, 2008.

Delattre, Alain. "Une liste de propriétés foncières du monastère d'Apa Apollô de Baouît." Zeitschrift für Papyrologie und Epigraphik 151 (2005): 163-165.

Delattre, Alain. Papyrus coptes et grecs du monastère d'apa Apollô de Baouît conservés aux Musées royaux d'Art et d'Histoire de Bruxelles. Bruxelles: Académie Royale de Belgique, 2007.

Gascou, Jean. "Les grands domaines, la cité et l'état en Égypte byzantine (recherches d' histoire agraire, fiscale et administrative)." Travaux et Mémoires: Centre de Recherches d'histoire et de civilisation byzantines 9 (1985): 1-9o.

Lemaire, Florence. "Antimisthosis in the Dioscorus Archive." In Proceedings of the Twenty-Fifth International Congress of Papyrology, Ann Arbor 2007, edited by Traianos Gagos, 397-408. American Studies in Papyrology. Ann Arbor: University of Michigan Press, 2010.

Richter, Tonio Sebastian. "Alte Isoglossen im Rechtswortschatz koptischer Urkunden." Lingua Aegyptia 10 (2002): 389-399.

Richter, Tonio Sebastian. "Koptische Mietverträge über Gebäude und Teile von Gebäuden.” The Journal of Juristic Papyrology 32 (2002): 113-168.

mary of the aparche documents, and 203-204 for instances of Arab names occurring in documents. 
Richter, Tonio Sebastian. Rechtssemantik und forensische Rhetorik: Untersuchungen zu Wortschatz, Stil und Grammatik der Sprache koptischer Rechtsurkunden. Leipzig: Verlag Helmar Wodtke und Katharina Stegbauer GbR, 2002. Revised edition: Wiesbaden: Harrassowitz, 2008.

Richter, Tonio Sebastian. “Ein neues Dossier zur Kloster-Papyrologie.” Orientalistische Literaturzeitung 99 (2004): 168-180.

Richter, Tonio Sebastian. "The Cultivation of Monastic Estates in Late Antique and Early Islamic Egypt: Some Evidence from Coptic Land Leases and Related Documents." In Monastic Estates in Late Antique and Early Islamic Egypt (P.Clackson), edited by Anne Boud'hors, James Clackson, Catherine Louis and Petra Sijpesteijn, 205-215. Cincinnati, Ohio: American Society of Papyrologists, 2009.

Schenke, Gesa. Kölner ägyptische Papyri (P.Köln ägypt.), vol. 2, Koptische Urkunden der früharabischen Zeit. Abhandlungen der Nordrhein-Westfälischen Akademie der Wissenschaften und der Künste. Papyrologica Coloniensia 9. Paderborn:Schöningh, 2016.

Till, Walter C. "Beiträge zu W.E. Crums Coptic Dictionary." Bulletin de la Société d'Archéologie copte 17 (1963-1964): 197-224.

Wegner, Joanna. "The Bawit Monastery of Apa Apollo in the Hermopolite Nome and its Relations with the 'World Outside." The Journal of Juristic Papyrology 46 (2016): 147-274.

Wipszycka, Ewa. Les resources et les activités économiques des églises en Égypte du IV au VIII ${ }^{e}$ siècle. Brussels: Fondation égyptologique Reine Elisabeth, 1972.

Wipszycka, Ewa. "Le fonctionnement interne des monastères et des laures en Égypte du point de vue économique: à propos d'une publication récente de textes coptes de Bawit." The Journal of Juristic Papyrology 31 (2001): 169-186.

Wipszycka, Ewa. Moines et communautés monastiques en Égypte (IV ${ }^{e}-\mathrm{VIII}^{e}$ siècles). JJP Supplement XI. Warsaw: Journal of Juristic Papyrology, 2009.

Wipszycka, Ewa. "Resources and Economic Activities of the Egyptian Monastic Communities (fourth-eighth Century)." The Journal of Juristic Papyrology 41 (2011): 159263 .

Worp, Klaas A. “Deliveries for CYNH@EIA in Byzantine Papyri." In Essays and Texts in Honor of J. David Thomas, edited by Traianos Gagos and Roger S. Bagnall, 51-68. Cincinnati, Ohio: American Society of Papyrologists, 2001. 